Błażej Kmieciak

Uniwersytet Medyczny w Łodzi

\title{
Przymus leczenia osób uzależnionych od alkoholu: perspektywa dylematów prawno-etycznych ${ }^{*}$
}

\author{
Compulsive treatment of alcohol addicts: the perspective \\ of legal and ethical dilemmas
}

\begin{abstract}
Abstrakt
W Polsce od ponad trzech dekad obowiązują zapisy ustawy o przeciwdziałaniu alkoholizmowi i wychowaniu w trzeźwości. Pojawienie się wskazanego dokumentu posiadało trudne do przecenienia społeczne znaczenie. W latach 70. i 80. ubiegłego wieku można było dostrzec wyraźną korelację pomiędzy wzrostem poziomu spożywania alkoholu oraz pojawieniem się coraz poważniejszych dramatów wewnątrzrodzinnych. Antyalkoholowa ustawa miała wprowadzić istotne normy dotyczące sprzedaży produktów alkoholowych. Jednocześnie skonstruowała ona - obowiązujące do dzisiaj - zasady kierowania osób uzależnionych na przymusową terapię. Wątek przymusowego leczenia osób uzależnionych od alkoholu jest nadal szeroko dyskutowany jest w literaturze zarówno prawniczej, medycznej, jak i psychopedagogicznej. Spotkać się można z postawą, zgodnie z którą jedynie dobrowolnie wyrażona zgoda na terapię umożliwia rozpoczęcie skutecznego procesu powrotu do zdrowia. $Z$ drugiej natomiast strony przypomina się, że w przypadku uzależnienia od alkoholu niejednokrotnie nie jest możliwe uzyskanie akceptacji pacjenta na leczenie. Zaznacza się, że dalsze trwanie w nałogu nieuchronnie prowadzi do cierpienia np. rodziny osoby nałogowo spożywającej alkohol. Dodaje się, że człowiek w podobnym stanie jest „zniewolony” przez alkohol. Uniemożliwia mu to podejmowanie racjonalnej decyzji, kluczowej dla niego oraz jego bliskich. W Polsce przymus leczenia szpitalnego dotyczący osób uzależnionych (poza wyjątkami) można stosować wyłącznie wobec osób, u których wykryto zespół zależności alkoholowej. Czy działania te posiadają nadal uzasadnienie? Czy działanie to ma na celu wyłącznie ochronę zdrowia osoby uzależnionej? Być może kluczowe jest w tym względzie przede wszystkim położenie, w jakim znajduje się rodzina osoby uzależnionej od alkoholu? Refleksja nad tymi pytaniami jest celem artykułu.
\end{abstract}

Słowa kluczowe: rodzina, prawa dziecka, uzależnienie od alkoholu, prawa człowieka, godność człowieka, demoralizacja

\section{Wprowadzenie}

Dokładnie ćwierć wieku temu swoją światową premierę miał film pt. Kiedy mężczyzna kocha kobietę. Produkcja ta do dzisiaj uznawana jest za jeden z najbardziej interesujących obrazów kinowych prezentujących problem uzależnienia

* Artykuł został przygotowany w ramach realizacji tematu badawczego „Prawno-społeczne wyzwania ochrony zdrowia psychicznego" nr 502-03/6-074-06/502-64-103 finansowanego ze środków Uniwersytetu Medycznego w Łodzi. W artykule zostały wykorzystane zmodyfikowane oraz przeredagowane fragmenty materiałów, które zebrał w trakcie opracowywania wcześniejszych publikacji dotyczących problematyki uzależnienia od alkoholu. 
od alkoholu ${ }^{1}$. W filmie zwrócona została uwaga na wskazane zagadnienie przede wszystkim z perspektywy sytuacji rodzinnej. Widz, wkraczając w świat relacji małżonków i rodziców wraz z koejnymi scenami, obserwuje dramat związany z cierpieniem bohaterów. Wprost związane jest ono z uzależnieniem od alkoholu Alice, głównej postaci granej przez Meg Ryan, która w pewnym momencie decyduje się poddać terapii w specjalnym ośrodku. Decyzja ta związana jest z sytuacją, jaka zapanowała w jej domu: konflikty z mężem, oddalenie się małżonków, utrata relacji z dziećmi. To terapia w całodobowej placówce staje się dla Alice realną szansą na naprawienie szkód wywołanych przez nałóg. Przywołana tutaj hollywoodzka produkcja jako jedna z pierwszych odniosła się do problemu uzależnienia kobiet. To także wskazany film ukazał realne znaczenie terapii odbywanej w wyspecjalizowanych placówkach, które pomimo wprowadzanych ograniczeń wynikających ze specyfiki leczenia w warunkach izolacyjnych proponują konkretne formy radzenia sobie z doświadczanym zaburzeniem².

Terapia uzależnień stanowi niezwykle specyficzny element wsparcia z zakresu ochrony zdrowia psychicznego. Można uznać wręcz, że tego typu oddziaływania wiązać się mogą z pojawieniem się kolejnych dylematów. Nie ulega bowiem wątpliwości, że wszelka forma działań medycznych kierowanych w stronę pacjenta winna opierać się na jego akceptacji i zgodzie. Mechanizm uzależnienia wiązać się może w sposób bezpośredni z negowaniem pojawiających się np. interpersonalnych trudności oraz wypieraniem problemów, jakie wystąpiły w rodzinie, której członkowie doświadczają skutków alkoholowego nałogu. Sytuacja ta ulega nieuniknionej komplikacji w momencie, w którym dana osoba kierowana jest na leczenie bez swojej zgody. Wymienić w tym miejscu można kilka istotnych dylematów oraz problemów: Czy można wkroczyć w autonomię pacjenta, zmuszając go do leczenia? Czy uzależniona osoba jest w stanie w obiektywny sposób ocenić swoją sytuację, jednocześnie odpowiedzialnie decydując o ewentualnym leczeniu? Czy przymusowa terapia nie narusza ex definitione praw pacjenta? Czy w terapii uzależnień kluczowe jest zdrowie osoby doświadczającej wskazanego zaburzenia psychicznego, czy też szeroko rozumiane dobro rodziny narażonej na straty?

Proponowane poniżej rozważania mają na celu podjęcie próby udzielenia odpowiedzi na wskazane wątpliwości. Kluczowe wydaje się jednak najpierw zwrócenie uwagi na zjawisko, jakim jest uzależnienie. W następnym etapie konieczne jest ukazanie prawnych podstaw podjęcia działań terapeutycznych bez zgody pacjenta. W kolejnej części, bazując na informacjach zaczerpniętych z literatury przedmiotu, podjęta zostanie refleksja dotycząca współczesnych dylematów rodzących się przy okazji omawiania tematu przymusowej hospitalizacji osób uzależnionych od alkoholu.

1 Do podobnych wniosków dochodzą m.in. czytelnicy najpopularniejszego w Polsce portalu filmweb.pl będącego źródłem informacji o produkcjach kinowych.

2 Zob. więcej na temat ww. filmu: M. Salwowska, recenzja: Kiedy mężczyzna kocha kobietę, „Kultura Dobra”, http://kulturadobra.pl/kiedy-mezczyzna-kocha-kobiete/ (data dostępu: 11.06.2019). 


\section{Zjawisko uzależnienia}

Problematyka działań przymusowych podejmowanych wobec osoby uzależnionej wzbudza szczególne zainteresowanie w kontekście szeroko rozumianych dyskusji prawno-medycznych. Natrafiamy w tym miejscu na wspomniane już powyżej kluczowe dla procesu diagnostyczno-terapeutycznego zagadnienie autonomii pacjenta. By w sposób pełny odnieść się do prawnych możliwości potencjalnego wkroczenia we wskazaną sferę pacjenta, konieczne jest najpierw wyjaśnienie, czym jest uzależnienie, a następnie wskazanie, jakie są obecnie przyjęte modele terapii osób nadużywających alkohol.

Jak zaznaczają Maciej Frąckowiak oraz Maciej Motyka przez zespół uzależnienia od alkoholu rozumiemy

zamiennie chorobę alkoholową, alkoholizm bądź uzależnienie od alkoholu - rozumiany jest jako zaburzenie polegające na utracie kontroli nad ilością spożywanego alkoholu. Istotnie, trudność z kontrolowaniem ilości wypijanego alkoholu jest kluczowa i stanowi podstawę do diagnozy choroby alkoholowej, jednak wieloletnie badania wykazały, iż jest to zaburzenie wieloaspektowe, obejmujące właściwie wszystkie obszary życia człowieka (Frąckowiak i Motyka, 2015, s. 317).

Warto w tym miejscu dodać, że omawiane schorzenie nie pojawia się u pacjenta w sposób nagły. Mowa jest raczej o wkraczaniu w kolejne fazy uzależnienia. Najpierw pojawia się tzw. picie towarzyskie. Następne etapy mają charakter ostrzegawczy oraz krytyczny. Ostatnia faza określana jest mianem chronicznej. Charakteryzuje ją: upijanie się w samotności, picie poranne, spadek tolerancji alkoholowej, sięganie po alkohol niespożywczy, psychoza alkoholowa, padaczka itd. (Frąckowiak i Motyka, 2015, s. 315-317). Pozostając w poruszonym tutaj wątku diagnostycznym, warto także zwrócić uwagę na spostrzeżenia Sebastiana Matyjaka, który stwierdza, że uzależnienie oznacza

niezwykle silne przywiązanie do środka psychoaktywnego i utratę kontroli nad jego przyjmowaniem. Głównym objawem zespołu uzależnienia jest silne pragnienie, wyrażające się poczuciem przymusu przyjęcia substancji psychoaktywnej w celu osiągnięcia przyjemności, a najczęściej po to, by zapobiec objawom dyskomfortu fizycznego lub psychicznego z powodu braku tego środka w organizmie. Uruchamia się mechanizm sprężenia, wzmagając u danej osoby skłonność do ponownego przyjęcia tej substancji (Matyjek, 2016).

Charakterystyka zjawiska, jakim jest uzależnienie, w tym zależność alkoholowa, skłania do stwierdzenia, że wskazując na formy możliwych działań leczniczych, skupić się należy na interwencjach psychoterapeutycznych, a nie farmakoterapeutycznych.

Zdaniem Czesława Cekiery działanie terapeutyczne kierowane w stronę omawianej grupy pacjentów to proces złożony. Osoba w podobnym stanie doświadcza nie tylko konkretnych objawów psychofizycznych. U pacjenta tego widać bowiem przede wszystkim wyraźne zaburzenie zdolności empatycznych. Osoba ta nie prezentuje krytycznego podejścia do sytuacji, w jakiej się znajduje. Jednocześnie coraz trudniej orientuje się, że jej własne działanie powodować może cierpienie bliskich jej osób. Cekiera zaznacza, że zależność alkoholowa 
jest z całą pewnością chorobą. Stanu tego nie można określić mianem np. „moralnego zaburzenia”. Jest to natomiast schorzenie wymagające zarówno psychoterapii, jak i resocjalizacji podejmowanej w określonych ośrodkach leczniczych. Wskazany w tym miejscu badacz dodaje w tym kontekście, że sukces w terapii zależy od motywacji pacjenta. Proces leczenia podzielić można zasadniczo na dwa etapy: odwykowy (krótkoterminowy bazujący na detoksykacji), a także resocjalizacyjno-terapeutyczny (jego celem jest wypracowanie utrwalonej zmiany u pacjenta) (Cekiera, 2009).

Warto w tym miejscu dostrzec, że uzależnienie nadal nie jest w pełni poznanym zjawiskiem. Odnosi się ono do wszelkich obszarów funkcjonowania człowieka. Marcin Wnuk oraz Jerzy T. Marcinkowski zauważają, że

[p]icie w nadmiarze ma swoje negatywne konsekwencje dla funkcjonowania fizycznego, psychicznego, społecznego i duchowego alkoholika. [...] Dopiero oddziaływania w wymiarze fizyczno-psychiczno-duchowym zgodne z holistyczną koncepcją człowieka mogą stać się solidną podstawą trzeźwienia i przyczynić się do dalszego i pełniejszego rozwoju jednostki (Wnuk i Marcinkowski, 2012, s. 52-53).

Przechodząc do konkluzji wstępnych rozważań, warto przywołać uwagi wyrażone przez Bogusława Habrata. Jego zdaniem współczesne formy terapii uzależnień posiadają charakter eklektyczny: Po pierwsze pacjent berze udział w działaniach opartych na edukacyjnych procedurach. Po drugie podejmowane są behawioralno-poznawcze interwencje terapeutyczne. Jest tu także trzecia płaszczyzna. Szczególną bowiem rolę w działaniach leczniczych mają ruchy samopomocowe, bazujące często na modelu społeczności terapeutycznej. To właśnie w grupie ukazywane są w sposób najszybszy autodestrukcyjne zachowania pacjenta. Grupa pełni w istocie rolę „zbiorowego lekarza”, który w sposób bardzo szybki potrafi zlokalizować prawdziwy problem pacjenta. Na kolejnych etapach jest on uczony rozpoznawania własnych stanów emocjonalnych (Habrat, 2006, s. 247).

\section{Przymus leczenia osób uzależnionych od alkoholu}

Zdaniem Justyny Zajdel „leczenie osób uzależnionych od alkoholu jest co do zasady dobrowolne, podobnie jak w przypadku osób uzależnionych od narkotyków. Zgodnie z ustawą o wychowaniu w trzeźwości i przeciwdziałaniu alkoholizmowi przymusowe skierowanie na leczenie odwykowe może odbywać się za zgodą sądu" (Zajdel, 2007, s. 43). Jak dodaje w tym kontekście Dorota Karkowska, w podobnych postępowaniach w pierwszej kolejności należy jednak podjąć działania mające na celu przekonanie danej osoby do dobrowolnego poddania się terapii (Karkowska, 2004) Tym samym możliwość przymusowego leczenia osób uzależnionych od alkoholu nie zwalnia personelu od aktywnego działania mającego na celu uzyskanie zgody pacjenta (Karkowska, 2004, s. 344-345).

Wskazana powyżej możliwość podjęcia działań przymusowych wobec pacjenta uzależnionego najczęściej kieruje nas w stronę treści ustawy o wychowaniu 
w trzeźwości i przeciwdziałaniu alkoholizmowi (Ustawa z dnia 26 października 1982 r. o wychowaniu w trzeźwości i przeciwdziałaniu alkoholizmowi, Dz.U. z 1982 r. Nr 35, poz. 230). Pierwszym elementem wskazanego aktu prawnego jest preambuła, na którą składa się jedno zdanie: „Uznając życie obywateli w trzeźwości za niezbędny warunek moralnego i materialnego dobra Narodu, stanowi się, co następuje”. „Trzeźwość” tym samym uznana została za cenną społecznie wartość. Uzależnienie natomiast zdefiniowane zostało jako konkretne zagrożenie zarówno dla jednostki, jak i dla społeczeństwa (Kubiak, 2010, s. 396).

W omawianej w tym miejscu ustawie działania przymusowe w stosunku do osób nadużywających alkohol opisane zostały w rozdziale 2. Zgodnie $z$ art. 23 ustawy osoby doświadczające szkody w związku z nadużywaniem przez członka rodziny alkoholu mają prawo do bezpłatnego wsparcia terapeutycznego. Chodzi tutaj przede wszystkim o osoby współuzależnione, które na co dzień doświadczają cierpienia związanego z nałogiem osoby bliskiej. Warto jednakże pamiętać w tym kontekście, że mowa jest także o dorosłych osobach, które zmagają się z problemami emocjonalnymi związanymi z wcześniejszą, trudną sytuacja rodzinną (Polak, 2014, s. 9, 18).

W art. 24 ustawy o wychowaniu w trzeźwości zaznaczono, że: „Osoby, które w związku z nadużywaniem alkoholu powodują rozkład życia rodzinnego, demoralizację małoletnich, uchylają się od pracy albo systematycznie zakłócają spokój lub porządek publiczny, kieruje się na badanie przez biegłego w celu wydania opinii w przedmiocie uzależnienia od alkoholu i wskazania rodzaju zakładu leczniczego”. Z kolei art. 26 tejże ustawy uzupełnia: „Osoby, o których mowa w art. 24, jeżeli uzależnione są od alkoholu, zobowiązać można do poddania się leczeniu w stacjonarnym lub niestacjonarnym zakładzie lecznictwa odwykowego". W dalszej części wskazanego aktu prawnego zaznaczono, że wniosek ten kieruje gminna komisja rozwiązywania problemów alkoholowych ${ }^{3}$.

Ustawa o wychowaniu w trzeźwości przewiduje dwie możliwości poddania danej osoby badaniu przez biegłych. Ich zadaniem jest stwierdzenie istnienia, bądź też wykluczenie uzależnienia:

- Gminna komisja może kierować daną osobę na badanie przez biegłego. W analizowanej ustawie nie wprowadzono jednakże możliwości przymusowego stawiennictwa danej osoby.

- Wskazana komisja ma prawo skierowania do sądu wniosku bez posiadania odpowiedniej medycznej opinii. Kluczowe jest jednak tutaj przedstawienie sprawy przez najczęściej bliskich osoby uzależnionej. Wówczas to w gestii sądu opiekuńczego leży ewentualne uznanie za właściwe tego typu diagnostyczne działanie: jest to niezbędne do wszczęcia omawianego, przymusowego postępowania. Zgodnie z treścią art. 30 ust. 1 ustawy o wychowaniu w trzeźwości w sytuacji „nieusprawiedliwionego niestawiennictwa na rozprawę lub uchylania się od zarządzonego poddania się badaniu przez biegłego albo obserwacji w zakładzie leczniczym sąd może zarządzić przymusowe doprowadzenie przez organ Policji".

W art. 34 ust. 1 omawianej ustawy zwrócona została uwaga na okres potencjalnego działania terapeutycznego podejmowanego na postawie omawianej

3 Wniosek taki złożyć może również sama osoba uzależniona. 
procedury. Jak zaznaczono w przywołanym unormowaniu: „Obowiązek poddania się leczeniu trwa tak długo, jak tego wymaga cel leczenia, nie dłużej jednak niż 2 lata od chwili uprawomocnienia się postanowienia". Należy w tym miejscu przywołać opinię, jaką wyraził Jędrzej Bujny. Jego zdaniem dwuletni okres to de facto górna granica. Jest to tym samym ostateczny czas pozwalający na poddawanie pacjenta terapii. Badacz podkreśla jednak, że nie jest to okres w żaden sposób formalnie wymagany (Bujny, 2006, s. 300). Jak zaznaczono bowiem w art. 34 ust. 4 ustawy o wychowaniu w trzeźwości: „O ustaniu obowiązku poddania się leczeniu przed upływem okresu wskazanego w ust. 1 decyduje sąd na wniosek osoby zobowiązanej, zakładu leczącego, kuratora, prokuratora lub z urzędu, po zasięgnięciu opinii zakładu, w którym osoba leczona przebywa".

Warto w tym miejscu zwrócić uwagę, że także inne ustawy odnoszące się do szeroko rozumianej rzeczywistości zdrowotnej wskazują na możliwość podjęcia działań przymusowych wobec osób uzależnionych od alkoholu. Warto w tym miejscu wskazać ustawę o ochronie zdrowia psychicznego (ustawa o o.z.p.). Choć ustawa ta nie odnosi się bezpośrednio do przywołanego zagadnienia, to jednak w jej treści dostrzec można dwa istotne elementy dotyczące omawianej materii. Warto je wymienić:

- zgodnie z art. 3 pkt 2 lit. d ustawy o o.z.p. szpitalem psychiatrycznym nazywamy także zakład opieki zdrowotnej sprawujący „całodobową opiekę psychiatryczną lub odwykową, niezależnie od podmiotu, który je tworzy i utrzymuje",

- uzależnienie, w tym uzależnienie od alkoholu, zakwalifikować należy, jako „inne zakłócenia czynności psychicznych, które zgodnie ze stanem wiedzy medycznej zaliczane są do zaburzeń psychicznych, a osoba ta wymaga świadczeń zdrowotnych lub innych form pomocy i opieki niezbędnych do życia w środowisku rodzinnym lub społecznym" (por. art. 3 pkt 1 lit. C u.or.z.p.) (zob. Lowe, 2001, s. 102-105).

Odnosząc się do relacji istniejącej pomiędzy leczeniem odwykowym osób uzależnionych od alkoholu a przymusem leczenia psychiatrycznego, należy zwrócić uwagę również na inny obszar. Istnieje bowiem możliwość podejmowania działań przymusowych wobec osób uzależnionych od alkoholu w kontekście stanu określanego mianem majaczenia alkoholowego. Jest to stan, w którym pacjent z powodu silnych objawów odstawiennych doświadcza zaburzeń o charakterze psychotycznym. Mowa w tym miejscu zwłaszcza o tzw. objawach pozytywnych, a zatem omamach słuchowych, wzrokowych oraz urojeniach (fałszywych przekonaniach uznanych przez pacjenta za prawdziwe). W sytuacji tej pacjent przyjmowany jest do placówki psychiatrycznej nie jako osoba uzależniona. Przyczyną leczenia bez zgody jest natomiast zespół objawów charakterystyczny dla choroby psychicznej. Pacjent wymaga w tej sytuacji natychmiastowego wsparcia medycznego, stanowi on bowiem zagrożenie dla własnego życia lub życia i zdrowia innych osób (Habrat, 2006, s. 244-245)4.

4 Tytułem uzupełnienia należy nadmienić, że w praktyce klinicznej spotkać można termin Mentally ill chemical Abusir (MICA). Jacqueline Cohen oraz Stephen Jay Levy podkreślają, że dotyczy on osoby, która cierpi na chorobę psychiczną. Jednocześnie stwierdza się u niej uzależnienie od alkoholu lub innych substancji psychoaktywnych (zob. Cohen i Levy, 1998, s. 9). 
Na koniec tej części rozważań warto zauważyć, że przymusowe leczenie w szpitalu psychiatrycznym niejednokrotnie mylone jest z pojęciem ubezwłasnowolnienia. Odnosząc powyższe spostrzeżenia do problemu osób uzależnionych od alkoholu, warto przypomnieć, że kodeks cywilny oraz kodeks postępowania cywilnego przewidują możliwość ubezwłasnowolnienia danej osoby nie tylko z powodu występowania choroby psychicznej, lub upośledzonych umysłowo, ale również w sytuacji wystąpienia uzależnienia od alkoholu lub narkotyków. Warunkiem podjęcia podobnych działań jest stwierdzenie przez biegłych (a wcześniej przez specjalistów wystawiających zaświadczenie z poradni leczenia uzależnień), że dana osoba, znajdując się $w$ tym stanie, nie potrafi podejmować racjonalnych oraz krytycznych decyzji, a w konsekwencji nie umie zaspokajać podstawowych potrzeb życiowych (Andrzejewski, 1999, s. 134-137). Wejście w życie przepisów Konwencji o prawach osób niepełnosprawnych ${ }^{5}$, a zwłaszcza art. $12^{6}$, spowodowało, że pojawiły się wyraźne wątpliwości w zakresie możliwości orzekania o ubezwłasnowolnieniu. Choć strona polska wyraziła zastrzeżenia odnośnie możliwości likwidacji w naszym kraju wskazanej instytucji prawnej, to jednak dostrzec trzeba, że Konwencja kładzie nacisk na rezygnację przez Państwa-Strony z podobnej formy zabezpieczenia interesów osoby niepełnosprawnej. Beata Janiszewska zwróciła w tym kontekście uwagę na istotny problem orzeczniczy. Część bowiem sądów okręgowych zawiesiło postępowania w podobnym zakresie, nie wiedząc, czy w obecnej sytuacji (konfliktu przepisów kodeksowych z przepisami Konwencji) możliwe jest na gruncie polskiego prawa orzekanie ubezwłasnowolnienia. Jej zdaniem działania takie w wypadku osób uzależnionych są obecnie podejmowane niezwykle rzadko ${ }^{7}$. Wydaje się, że stan ten spowodowany jest $w$ istocie nieefektywnością podobnych interwencji kierowanych w stronę osoby

5 Konwencja o prawach osób niepełnosprawnych, sporządzona w Nowym Jorku dnia 13 grudnia 2006 r. (Dz.U. z 2012 r., poz. 1169).

6 „1. Państwa-Strony potwierdzają, że osoby niepełnosprawne mają prawo do uznania w każdym miejscu za podmioty osobowe wobec prawa. 2. Państwa-Strony stwierdzają, iż osoby niepełnosprawne mają taką samą zdolność prawną we wszystkich aspektach życia jak inni obywatele. 3. Państwa-Strony podejmą właściwe kroki, aby zapewnić dostęp osobom niepełnosprawnym do pomocy, jakiej mogą wymagać w korzystaniu ze swojej zdolności prawnej. 4. Państwa-Strony zagwarantują, iż wszystkie środki i działania odnoszące się do korzystania ze zdolności prawnej zapewnią właściwe i efektywne instrumenty stanowiące ochronę przed nadużyciami, zgodnie z międzynarodowym ustawodawstwem dotyczącym praw człowieka. Te instrumenty ochronne zagwarantują to, że środki i działania odnoszące się do korzystania ze zdolności prawnej, będą podejmowane w poszanowaniu praw, woli i preferencji danej osoby, zapobiegną konfliktowi interesów i wywieraniu nieuzasadnionego wpływu, będą proporcjonalne i dopasowane do okoliczności, w jakich dana osoba się znajduje, będą stosowane w możliwie krótkim okresie oraz będą podlegać regularnej rewizji przez kompetentny i bezstronny organ lub władze sądownicze. Instrumenty będą proporcjonalnę do stopnia, w jakim wyżej wymienione działania i środki oddziaływają na prawa i interesy tej osoby. 5. Zgodnie z postanowieniami niniejszej Konwencji, Państwa-Strony podejmą wszelkie stosowne i skuteczne działania dla zapewnienia osobom niepełnosprawnym równego prawa do posiadania lub dziedziczenia własności, sprawowania kontroli nad własnymi finansami oraz dostępu do pożyczek bankowych, kredytów hipotecznych i innych form kredytów finansowych na równych zasadach z innymi obywatelami oraz zagwarantują, iż osoby niepełnosprawne nie będą arbitralnie pozbawiane swojej własności".

7 Uwagi te B. Janiszewska wyraziła w trakcie konferencji „Autyzm a prawo”, która odbyła się na Uniwersytecie Medycznym w Białymstoku 16 kwietnia 2018 r. 
uzależnionej. Pojawia się bowiem pytanie: Po co podejmować tego typu interwencje formalne wobec wskazanej grupy osób? Oczywiste, że konieczne jest zabezpieczenie interesów osoby doświadczającej zespołu zależności alkoholowej. Równie ważne może być położenie rodziny narażonej na straty finansowe będące efektem nieracjonalnych działań człowieka doświadczającego silnego nałogu. Z perspektywy praktycznej jednakże pozbawienie osoby uzależnionej od alkoholu zdolności do czynności prawnej okazać się może dalece nieefektywne. Polskie przepisy prawno-medyczne bardzo wyraźnie wskazują, że osoba ubezwłasnowolniona całkowicie, pomimo swojej sytuacji formalnej, posiada prawo do wyrażenia stosunku w zakresie podejmowanych wobec niej działań diagnostyczno-terapeutycznych ${ }^{8}$. Innymi słowy - nawet gdyby opiekun prawny osoby uzależnionej i ubezwłasnowolnionej chciał skierować ją bez zgody na terapię odwykową, wówczas jej sprzeciw mógłby zastopować podobne działanie. Warto także zaznaczyć, że mogłoby okazać się ono niemożliwe również ze strony terapeutów, którzy widząc brak woli poddania się leczeniu, uznać by mogli, że interwencja psychokorekcyjna w podobnym przypadku byłaby nieefektywna oraz nieetyczna.

\section{Refleksje w stronę dylematów}

Ukazana powyżej sytuacja kieruje nas w stronę dylematów, jakie nadal spotykamy, podejmując się analizy tematu terapii uzależnień, w tym zwłaszcza przymusowego charakteru podobnych interwencji. We wstępie została zwrócona w tym kontekście uwaga najpierw na następującą wątpliwość: Czy można wkroczyć w autonomię pacjenta, zmuszając go do leczenia? Odpowiadając na wskazane pytanie na poziomie wyłącznie formalno-prawnym, należy z całą pewnością stwierdzić, że podobne działanie jest w pełni możliwe. Wskazana powyżej ustawa o wychowaniu w trzeźwości i przeciwdziałaniu alkoholizmowi zezwala, by podjąć wobec osoby uzależnionej tego typu interwencje. Nadal jednak dostrzec trzeba inną kwestię wprost związaną z sensownością oddziaływań kierowanych wobec osób doświadczających zespołu zależności alkoholowej. Pisząc wprost, trzeba zaznaczyć, że mowa jest tutaj o pacjentach, którzy niejednokrotnie nie maja motywacji do podjęcia działań leczniczych. Powyżej zwrócona została uwaga na następującą wątpliwość: Czy uzależniona osoba jest w stanie w obiektywny sposób ocenić swoją sytuację, jednocześnie odpowiedzialnie decydując o ewentualnym leczeniu? W przedstawionych wcześniej uwagach praktycznych oraz opiniach zaczerpniętych z piśmiennictwa dostrzec można bezsprzecznie, że umiejętność racjonalnej oceny własnej sytuacji jest w przypadku uzależnionego pacjenta dalece ograniczona. Rozpatrując zatem z perspektywy praw pacjenta problem przymusowych interwencji terapeutycznych wobec osób doświadczających tego typu zaburzeń, podzielić należy pogląd wyrażony ponad dekadę temu przez Jędrzeja

8 Zob. w tym kontekście w sposób szczególny art. 32 ust. 4 i 6 oraz art. 34 ust. 6 Ustawy z dnia 5 grudnia 1996 r. o zawodach lekarza i lekarza dentysty (Dz.U. Nr 226, poz. 1943 z późn. zm.). 
Bujnego. Jego zdaniem, odnosząc się do problematyki pacjenckich uprawnień, dostrzec trzeba w istocie dualny charakter wskazanego tutaj de facto zjawiska o społecznym charakterze. Prawa pacjenta znajdują się bowiem „między autonomią a paternalizmem" (zob. Bujny, 2006). Z jednej strony pełnoletni pacjenci posiadają prawo do decydowania o własnym losie: to oni ostatecznie decydują, czy zrealizowane zostaną proponowane im oddziaływania diagnostyczno-terapeutyczne (Gmurzyńska i Morek, 2011, s. 44-45). Z drugiej jednak strony zarówno krajowe, jak i międzynarodowe akty prawne zezwalają na wkroczenie we wskazany autonomiczny obszar. W interesujący sposób postawę paternalistyczną - w odniesieniu do pacjentów z zaburzeniami psychicznymi - ukazał Stanisław Dąbrowski. Psychiatra, a zarazem współtwórca polskiej ustawy o ochronie zdrowia psychicznego ${ }^{9}$, przypomniał, że ukazując paternalizm, trzeba pamiętać zarówno o wersji „twardej”, jak i „miękkiej”. Pierwszą z postaw charakteryzuje całkowite pominięcie przez medyka perspektywy przyjmowanej przez osobę chorą/doświadczającą zaburzenia. Kluczowe jest zdanie lekarza/terapeuty ${ }^{10}$. Druga, „miękka” odsłona ma zupełnie inny kontekst. Tutaj także ekspert wkracza $\mathrm{w}$ autonomię osoby poddawanej diagnozie i terapii. Interwencja ta podjęta jest jednak z racji obiektywnego, dostrzeganego dobra osoby leczonej, która z racji doświadczanych objawów choroby stwarzać może dla siebie lub innych zagrożenie. Dąbrowski wydaje się trafnie lokalizować w tym kontekście paradoks: wkroczenie $\mathrm{w}$ autonomię $\mathrm{w}$ obszarze praw pacjenta prowadzić może do pełnej realizacji owych uprawnień (w tym prawa do świadczeń zdrowotnych w sytuacji niebezpiecznej dla zdrowia) (zob. Dąbrowski, 1995). Tym samym uzasadnione nie tylko klinicznie, ale i moralnie, wydaje się wkroczenie w unikalną sferę wolności człowieka. Celem nie jest tutaj jakiekolwiek naruszenie godności danej osoby zdominowanej przez medycznego specjalistę. Mowa tutaj raczej o zabezpieczeniu człowieka przed nim samym ${ }^{11}$.

Podobne rozważania kierują nas w stronę następnego wyrażonego powyżej pytania: Czy przymusowa terapia nie narusza ex definitione praw pacjenta? Częściowo wątpliwość ta została już wyjaśniona. $Z$ całą pewnością podejmowanie działań przymusowych wobec pacjentów zawsze grozi pojawieniem się negatywnych skutków, chociażby w postaci naruszenia konkretnych praw. Mowa zwłaszcza o sytuacjach, w których dochodzi do negatywnych konsekwencji związanych z naruszeniem godności pacjenta, jego intymności, a czasem również wolności: pacjent oczekuje zgody na wyjście ze szpitala, której nie dostaje. W tym kontekście kluczowe wydaje się zrozumienie specyfiki oddziaływań terapeutycznych kierowanych w stronę pacjentów doświadczających ZZA, czyli Zespołu Zależności Alkoholowej. W piśmiennictwie, jak stwierdzono wcześniej,

9 Ustawa z dnia 19 sierpnia 1994 r. o ochronie zdrowia psychicznego (Dz.U. Nr 111, poz. 535 z późn. zm.).

10 Oddaje ją bardzo mocno filmowa postać dra House'a skupionego często na rozwiązaniu zagadki medycznej, a nie wyleczeniu konkretnej osoby (zob. Henry i William, 2009).

11 Podobna sytuacja występuje np. w kontekście oddziaływań terapeutycznych kierowanych w stronę osób małoletnich, nie w pełni rozumiejących sytuację, w jakiej się znajdują. Szczególnie mowa tutaj o stosowaniu wobec np. pobudzonych pacjentów przymusu bezpośredniego w ORM-ie, np. unieruchomienia (zob. Kmieciak, 2017, s. 93). 
szczególne znaczenie ma socjoterapia. To ona bowiem pozwala często na zlokalizowanie problemów, które są przemilczane przez pacjentów, a które są jednocześnie niezbędne do wprowadzenia skutecznej zmiany. Trzeba jednakże dodać, że leczenie w ośrodkach zamkniętych bardzo często opiera się na realizacji ustalonego kontraktu (Bakuła, 2012) ${ }^{12}$. Pacjent zobowiązany jest do przestrzegania regulaminu oddziału/placówki. Łamanie jego zasad prowadzić może do konsekwencji w postaci przerwania terapii. Jest to forma oddziaływań behawioralno-poznawczych, w których to pacjent doświadcza pozytywnych lub negatywnych konsekwencji swoich działań. Tym samym ignorując. zasady np. obowiązkowego udziału w zajęciach, abstynencji od alkoholu, współodpowiedzialności za porządek w oddziale, pacjent naraża się na konsekwencje w postaci nagłego przerwania terapii, ergo zerwania kontraktu terapeutycznego zawartego przed leczeniem. Ostatni z wskazanych tutaj obowiązków pacjenta jest ciekawy. Zgodnie z treścią art. 15 ust. 1 ustawy o ochronie zdrowia psychicznego: „Zajęcia rehabilitacyjne prowadzone w szpitalach psychiatrycznych i w domach pomocy społecznej nie mogą być podporządkowane celom gospodarczym"13. Tym samym, by działania porządkowe realizowane przez wspomnianą grupę pacjentów były zgodne z wymogami prawa, muszą one być wcześniej uzgodnione z pacjentem, winny posiadać wyraźny, terapeutyczny cel (forma ergoterapii) oraz nie powinny stanowić nieuzasadnionego wyręczania personelu utrzymującego czystość na oddziale. Problematyczne w omawianej sytuacji może okazać się zachowanie pacjenta kierowanego na terapię bez swojej zgody. Osoba ta, często niezmotywowana, negująca istniejący problem, może uznać, że łamanie regulaminu oddziału jest najlepszym sposobem zakończenia terapii. Naruszając zasady panujące na oddziale, będzie dążyć do szybszego opuszczenia placówki. Rodzi się w tym miejscu kolejny istotny problem. Jak bowiem zmotywować leczonego bez zgody pacjenta do terapii w momencie, gdy zaprzecza jej zasadności? Tutaj kluczowe okazać się może wsparcie wspominanej powyżej grupy socjoterapeutycznej, która ma możliwość wejścia w rolę „naturalnego autorytetu” pokazującego realne konsekwencje podjęcia lub nie podjęcia leczenia. Jak wskazuje bowiem słusznie Adam Bilikiewicz, pacjent jako uczestnik grupy socjoterapeutycznej „staje się współdecydentem w procesie leczenia [...] w istotnych dla niego sprawach organizacji oddziału" (Bilikiewicz, 2006, s. 725; Hoffmann i Prieb, 2005, s. 327-332). W trakcie podobnych spotkań niejednokrotnie pojawia się szczególny w kontekście uzależnienia problem dotyczący relacji w rodzinie osoby, która poddawana jest terapii, w tym także terapii jako osoba uzależniona. Powtarzając zatem wyrażone we wstępie pytanie, trzeba rozważyć: Czy w terapii uzależnień kluczowe jest zdrowie osoby doświadczającej wskazanego zaburzenia psychicznego, czy tez szeroko rozumiane dobro rodziny narażonej na straty?

12 Zob także: Rozporządzenie Ministra Zdrowia i Opieki Społecznej z dnia 6 maja 1983 r. w sprawie regulaminów stacjonarnych zakładów lecznictwa odwykowego oraz domów pomocy społecznej dla osób uzależnionych od alkoholu (Dz.U. Nr 25, poz. 115).

13 Zgodnie $z$ art. 3 pkt 2 lit. d ustawy o ochronie zdrowia psychicznego, wyrażenie szpital psychiatryczny odnosi się do „innego zakładu leczniczego podmiotu leczniczego w rozumieniu przepisów o działalności leczniczej, sprawującego całodobową opiekę psychiatryczną lub odwykową". 
Odpowiadając na wskazane w tym miejscu pytanie z perspektywy zasad wykonywania zawodu przez lekarza i terapeutę uzależnień, dojść trzeba do wniosku, że to perspektywa sytuacji, w jakiej znajduje się uzależniony pacjent, posiada szczególne znaczenie. W przypadku lekarza dojść trzeba do podobnego wniosku, odnosząc się m.in. do treści zarówno ustawy o zawodach lekarza i lekarza dentysty, jak i zapisów Kodeksu Etyki Lekarskiej (KEL). Pierwszy z wskazanych dokumentów nakazuje lekarzowi podjęcie działań w momencie, gdy zwłoka w ich wykonaniu groziłaby uszczerbkiem na zdrowiu pacjenta (w szczególności art. 30). Z kolei KEL w sposób wyraźny wskazuje na kluczową dla deontologii lekarzy zasadę „po pierwsze nie szkodzić” 14 . To zatem doświadczający ZZA pacjent winien znajdować się w centrum terapeutycznych oddziaływań. Nie można jednakże zapomnieć, że uzależnienie jest schorzeniem, które „promieniuje” na całą rodzinę. Można powiedzieć, że realnych trudności oraz cierpień doświadcza cała rodzina. Kontekst ten w sposób wyraźny ukazuje się w momencie podjęcia dyskusji dotyczących możliwości podjęcia przymusowej terapii wobec osoby mającej omawiany typ zaburzenia psychicznego. Warto odnotować, że polskie ustawodawstwo, odnosząc się do możliwości podjęcia terapeutycznych działań przymusowych, ukazuje nam rzeczywistość, którą określić należy mianem formalno-behawioralnej. Innymi słowy - pacjent nie może być przez sąd skierowany do oddziału terapeutycznego, jeśli jego uzależnienie nie wywołuje negatywnych skutków o społecznym charakterze. Owe skutki, zgodnie z treścią ustawy, winny odnosić się w sposób szczególny do sytuacji, jakiej doświadcza rodzina pacjenta, w tym także osoby małoletnie. Tym samym przymusowa terapia osób uzależnionych w sposób nieuchronny kieruje nas w stronę unikalnego dobra, jakim jest $m$.in. bezpieczeństwo rodziny oraz harmonijny rozwój dzieci (Kmieciak, 2017, s. 229-230). Wątek ten nie jest bez znaczenia dla aktualnej także w Polsce dyskusji prawno-rodzinno-społecznej. Uzależnienie od alkoholu prowadzić może bowiem do pojawienia się realnych, negatywnych konsekwencji zdrowotnych dla dzieci w fazie prenatalnej. Na wątek ten w ostatnich latach zwrócił uwagę Marek Michalak, który w 2018 r. po dziesięciu latach urzędowania przestał być Rzecznikiem Praw Dziecka. Wskazany tutaj dziecięcy ombudsman przypominał w swoich wypowiedziach, że alkohol spożywany przez kobiety w ciąży prowadzić może do pojawienia się u dzieci Alkoholowego Zespołu Płodowego (FAS - Fetal Alcohol Syndrome $)^{15}$, w sposób wyraźny opóźniającego ich rozwój psychofizyczny po narodzeniu. W pierwszej wersji zaproponowanego przez siebie nowego Kodeksu Rodzinnego zaproponował on możliwość podjęcia terapeutycznych działań przymusowych wobec uzależnionych od alkoholu oraz substancji

14 Ustawa z dnia 5 grudnia 1996 r. o zawodach lekarza i lekarza dentysty (Dz.U. Nr 226, poz. 1943 z późn. zm.), Kodeks Etyki Lekarskiej z dnia 2 stycznia 2004 r., (tekst jednolity; zawierający zmiany uchwalone w dniu 20 września 2003 r. przez Nadzwyczajny VII Krajowy Zjazd Lekarzy), Warszawa 2004.

15 Zob. Depesza, W Tomaszowie Mazowieckim pijana urodziła bliźniaki. „DziennikŁódzki”, http:// www.dzienniklodzki.pl/na-sygnale/a/w-tomaszowie-mazowieckim-pijana-urodzila-blizniaki,12558230/ (data dostępu: 14.06.2019) oraz Depesza, Zgierz. Pijana matka urodziła martwe dziecko. Sprawą zajęła się prokuratura. „Gazeta Wyborcza”, http://lodz.wyborcza.pl/lodz/7,35136,20688565,zgierz-pijana-matka-urodzila-martwe-dziecko-sprawa-zajela.html (data dostępu: 14.06.2019). 
psychoaktywnych kobiet w ciąży. Michalak zwracał bowiem uwagę, że polskie ustawodawstwo nie zezwala na podjęcie działań leczniczych wobec spodziewającej się dziecka kobiety nadużywającej np. alkoholu. Stan ten jego zdaniem prowadzić może do zdarzeń tragicznych, zwłaszcza w momencie, gdy kobieta, negując konieczność leczenia, nadal trwa w nałogu. Podobna procedura miała zostać objęta szczegółową kontrolą sądu, który de facto interweniowałby w celu ochrony dobra dziecka poczętego, które w podobnym ujęciu potraktowane by zostało jako członek rodziny ${ }^{16}$. Rzecznik Praw Dziecka podkreślał w liście do prezydenta Andrzeja Dudy, że

należy uruchomić procedurę, na podstawie której kobieta będąca w ciąży, działająca na szkodę swojego dziecka poprzez spożywanie alkoholu, narkotyków lub innych substancji psychoaktywnych, może zostać skierowana przez sąd na leczenie szpitalne we wskazanym zakładzie leczniczym. Procedura ta powinna być uregulowana na poziomie ustawowym, a odpowiednim miejscem dla nowych przepisów - zdaniem Rzecznika - jest KRiO, jako podstawa materialna oraz Kodeks postępowania cywilnego, jako podstawa procesowa (Michalak, 2017, s. 1).

Propozycja ta wzbudziła duże zainteresowanie, ale również i społeczne obawy dotyczące w istocie instytucjonalnej izolacji kobiet w ciąży. Podobne czynniki sprawiły, że w finalnej wersji projektu wspomnianego Kodeksu zrezygnowano z podobnych działań. Zaproponowano jedynie możliwość zobowiązania kobiety w ciąży do odbycia terapii w niestacjonarnym ośrodku leczenia uzależnień.

\section{Konkluzja}

Przymusowa hospitalizacja osoby doświadczającej określonych schorzeń w sposób naturalny wzbudza wątpliwości oraz pytania. Działania diagnostyczno-terapeutyczne nieuchronnie wkraczają w ludzką autonomię oraz intymność. Co więcej prowadzić mogą one do pojawienia się obaw oraz lęku. Paternalizm decyzyjny stanowi dzisiaj element, z którym medycyna pragnie ostatecznie się rozstać. To świadome współdziałanie lekarza (lub innego eksperta) z pacjentem traktowane jest jako szczególnie istotny element budowania płaszczyzny pozwalającej na skuteczne rozwiązanie problemu zdrowotnego. Tutaj jednak pojawia się istotna wątpliwość - czy pacjent posiada zawsze świadomość swojego złego położenia? Czy, jeśli jej nie posiada, istnieje możliwość, by wymóc na nim

16 Inne zdanie w tej kwestii wypracowała m.in. brytyjska judykatura. W jednej z prezentowanych w mediach spraw brytyjski sąd zadecydował o zaprzestaniu wypłacania świadczeń finansowych na dziecko, u którego wykryto liczne zaburzenia składające się na tzw. alkoholowy zespół płodowy (FAS). Matka, która otrzymywała je, wcześniej przyznała, że w trakcie ciąży regularnie spożywała alkohol, który zapewne przyczynił się do pojawienia się podobnego stanu u dziecka Tak opisywał wspomniana sprawę Łukasz Starożycki „[...] sąd apelacyjny orzekł o odebraniu chorej zapomogi. [...] świadczenie w tym przypadku nie przysługuje, ponieważ w czasie, gdy doszło do rozstroju jej zdrowia, nie była «osobą» w sensie prawnym, a jedynie swego rodzaju «organizmem»". Zob. szerzej Ł. Starożycki, Prawo do picia przed prawem do życia, „Nasz Dziennik”, http://www.naszdziennik.pl/ swiat/117771,prawo-do-picia-przed-prawem-do-zycia.html (data dostępu: 14.06.2019). 
poddanie się określonej interwencji? Czy przyniesie to spodziewany efekt? W przypadku osób małoletnich, doświadczających chorób zakaźnych oraz chorób psychicznych dojść można do wniosku, że np. przymusowa interwencja chirurgiczna lub farmakologiczna uchronić może pacjenta lub inne osoby przed np. złymi konsekwencjami dalszego trwania choroby. W przypadku osób uzależnionych od alkoholu nie ma już jednak takiej pewności. Osoby doświadczające ZZA najczęściej negują istnienie problemu i nie dostrzegają konieczności dokonania zmiany. Nie mają one zatem istotnej do terapii motywacji. Nie można jednakże pominąć $w$ tym miejscu położenia, w jakim znajdą się ich bliscy narażeni na negatywne konsekwencje nałogu. To właśnie wspótistnienie uzależnienia oraz wynikających z nich szkód rodzinno-społecznych polski ustawodawca uznał przed prawie czterema dekadami za czynniki uzasadniające podjęcie działań bez zgody osoby uzależnionej od alkoholu. Czy jednak podobne interwencje są skuteczne?

W połowie 2016 r. Najwyższa Izba Kontroli (NIK) opublikowała raport dotyczący kierowania osób uzależnionych od alkoholu na przymusowe leczenie na terenie placówki całodobowej. Jak wskazano:

Procedura przymusowego kierowania osób uzależnionych od alkoholu na leczenie odwykowe nie funkcjonuje sprawnie i nie wspomaga skutecznie rozwiązywania problemów alkoholowych. Ponad 60 procent zobowiązanych nie stawia się na leczenie, a 30 procent osób przyjętych na obowiązkową terapię nie kończy jej. Połowa zobowiązanych jest ponownie przymusowo kierowana na leczenie, a niemal tyle samo trafia na nie wielokrotnie.

\section{Eksperci NIK uzupełniają:}

Wyniki kontroli NIK pokazują, że realizacja procedury trwa zbyt długo. Od skierowania przez sąd na leczenie do podjęcia terapii średnio mijają niemal dwa lata. W tym czasie osoby uzależnione od alkoholu pozostają w swoich rodzinach i środowisku, nadal stwarzając zagrożenie dla życia i zdrowia domowników i sąsiadów. Procedura nie spełnia zatem ważnego celu, jakim jest ochrona rodziny i środowiska osoby nadużywającej alkoholu ${ }^{17}$.

Wobec treści podobnego dokumentu nie można przejść obojętne. Wskazuje on bowiem na konieczność podjęcia rzetelnej debaty dotyczącej systemu wsparcia osób uzależnionych. Omawiane tutaj wsparcie czasem musi zostać podjęte bez zgody osoby, która doświadczając zależności alkoholowej, nie jest krytyczna wobec swojego stanu. Interwencji przymusowej zawsze towarzyszą liczne dylematy, których rozwiązanie jest możliwe wyłącznie w momencie, w którym przepisy w sposób praktyczny umożliwiać będą działanie na rzecz pacjenta, a także jego bliskich.

Bez względu jednak na dynamikę zmian legislacyjnych w Polsce w omawianym tutaj zakresie konieczne jest podkreślenie, że uzależnienie od alkoholu jest przykładem stanu klinicznego, który niejednokrotnie zmusza personel do wkroczenia w autonomię pacjenta. Jego brak możliwości krytycznej i racjonalnej oceny

17 Komunikat: NIK o przymusowym kierowaniu na leczenie odwykowe, Serwis Najwyższej Izby Kontroli, https://www.nik.gov.pl/do_druku/typ,0,id,2621.html?referer=https://www.nik.gov.pl/aktualnosci/nik-o-przymusowym-kierowaniu-osob-uzaleznionych-od-alkoholu-na-leczenie-odwykowe.html (data dostępu: 14.06.2019). 
własnej sytuacji powodować może pojawienie się sytuacji, w której szczególnie istotne będzie zabezpieczenie pacjenta przed nim samym (przed efektami działań wprost wynikających z ZZA, a mogących stanowić zagrożenie dla pacjenta lub jego bliskich). Ukazana tutaj aktywność w żadnej mierze nie może być uznana za sprzeczną z koncepcją poszanowania praw pacjenta, w tym prawa do wyrażenia przez niego zgody oraz prawa do poszanowania godności. Opisane powyżej procedury odwołują się do znanych i sprawdzonych w demokratycznych systemach prawnych reguł sądowej kontroli działań podejmowanych przez personel medyczny. Sąd, wsparty opinią medycznego eksperta (biegłego), posiada narzędzia do obiektywnej oceny i ewentualnych działań przymusowych. W kontekście leczenia bez zgody osób doświadczającej zależności alkoholowej unikalne znaczenie posiada nie tylko stan zdrowia osoby nadużywającej alkohol, ale również sytuacja psychospołeczna jego bliskich, w tym zwłaszcza osób małoletnich.

\section{Bibliografia}

Andrzejewski M. (1999), Prawna ochrona rodziny, Wydawnictwa Szkolne i Pedagogiczne, Warszawa. Bakuła P. (2012), Regulaminy ośrodków a prawa człowieka i pacjenta, „Terapia” 5, s. 32-33.

Bilikiewicz A. (2006), Słownik terminologiczny, [w:] A. Bilikiewicz, Psychiatria - podręcznik dla studentów medycyny, PZWL, Warszawa.

Bujny J. (2006), Prawa pacjenta - między autonomia a paternalizmem, C.H. Beck, Warszawa.

Cekiera C. (2009), Alkoholizm, [w:] A. Muszala, Encyklopedia bioetyki, Polwen, Radom, s. 73-79.

Cohen J., Levy S.J. (1998), Chorzy psychicznie nadużywający substancji psychoaktywnych, Państwowa Agencja Rozwiązywania Problemów Alkoholowych, Warszawa.

Dąbrowski S. (1995), Prawa chorych psychicznie i przesłanki przymusowego postępowania [w:] M. Siwiak-Kobayashi, S. Leder (red.), Psychiatria i etyka, Komitet Redakcyjno-Wydawniczy Polskiego Towarzystwa Psychiatrycznego, Kraków, s. 53-60.

Gmurzyńska E., Morek R. (2011), O problemach dotyczących rozstrzygania spraw o błędy lekarskie i o roli mediacji rozstrzygania spraw o błędy lekarskie, „ADR Arbitraż i Mediacja” 3(15), s. 43-77.

Frąckowiak M., Motyka M. (2015), Zespół zależności alkoholowej: charakterystyka, fazy rozwoju, metody diagnozowania, „Problemy Higieny i Epidemiologii” 96(2), s. 315-320.

Habrat B. (2006), Zaburzenia psychiczne spowodowane przyjmowaniem substancji psychoaktywnych, [w:] A. Bilikiewicz, Psychiatria - podręcznik dla studentów medycyny, PZWL, Warszawa, s. 238-269.

Hoffmann K., Prieb S. (2005), Socjoterapia, [w:] H. Freyberger, W. Schneider, R. Stieglitz (red.), Kompendium psychiatrii, psychoterapii, medycyny ratunkowej, PZWL, Warszawa, s. 327-332

Jacoby H., William I. (2009), Dr House i filozofia - wszyscy kłamią, Wydawnictwo Helion, Gliwice.

Karkowska D. (2004), Prawa pacjenta, ABC, Warszawa.

Kmieciak B. (2017), Przymus leczenia osób uzależnionych od alkoholu: Archaizm prawa, czy też aktualność rozwiązań, „Fides et Ratio” 3, s. 221-239.

Kmieciak B. (2017), Etyczne oraz społeczne dylematy ochrony praw dziecka jako pacjenta szpitala psychiatrycznego, „Konteksty Społeczne” 2.

Kubiak R. (2010), Prawo medyczne, C.H. Beck, Warszawa.

Lowe G. (2001), Uzależnienie od alkoholu i narkotyków, [w:] A. Lazars, A. Locelam (red.), Psychopatologia, Zysk i S-ka, Warszawa, s. 102-125.

Matyjek S. (2016), Czy chcemy legalnych narkotyków?, „Acta Universitatis Lodziensis. Folia luridica" 76, s. 7-19.

Michalak M. (2017), List Rzecznika Praw Dziecka Marka Michalaka do Prezydenta RPAndrzeja Dudy, Biuro Rzecznika Praw Dziecka, Warszawa.

Polak G. (2014), Rozwinąć skrzydła, AMPoligrafia, Katowice. 
Ustawa z dnia 26 października 1982 r. o wychowaniu w trzeźwości i przeciwdziałaniu alkoholizmowi, Dz.U. z 1982 r. Nr 35, poz. 230.

Wnuk M., Marcinkowski J. (2012), Alkoholizm - przegląd koncepcji oraz metod leczenia, „Hygeia Public Health" 57, s. 49-55.

Zajdel K. (2007), Prawo w medycynie - podręcznik dla lekarzy, Progress, Łódź.

\begin{abstract}
In Poland, the provisions of the Act on Counteracting Alcoholism and Upbringing in Sobriety have been in force for more than three decades. It is hard to overstate the social impact this document has had since its emergence. In the 1970's and 1980's one could notice a clear correlation between the increase in the level of alcohol consumption and the emergence of increasingly serious crises within families. The anti-alcohol law was to introduce significant standards for the sale of alcohol products. At the same time it set up the principles of directing addicts to compulsory therapy, which have been in effect ever since. The topic of compulsory treatment of people addicted to alcohol is still widely discussed in both legal, medical and psycho-pedagogical literature. Some claim that only voluntary participation in therapy allows one to begin an effective recovery process. On the other hand, we are also reminded that in the case of alcohol addiction it is often not possible to obtain the patient's consent for treatment. It is noted that continuing addiction inevitably leads to the suffering of the family of the addict. Moreover, a person in a such a condition is said to be "enslaved" by alcohol. This prevents him from making rational decisions, crucial for him and his relatives. In Poland, compulsory hospital treatment for addicts (with exceptions) can only be applied to persons who have been diagnosed with alcohol dependency syndrome. Are such activities still justified? Is this action intended solely to protect the health of the addict? Perhaps the position of the addicted person's family is of key importance is in this regard? The aim of the article is to present deliberations on these questions.
\end{abstract}

Keywords: family, children's rights, alcohol addiction, human rights, human dignity, demoralization 